\title{
Analysis of artisanal fisheries in two reservoirs of the upper Paraná River basin (Southeastern Brazil)
}

\author{
José Luís Costa Novaes ${ }^{1}$ and Edmir Daniel Carvalho²
}

We compared the artisanal fisheries, in terms of catch strategies, productivity, and gross per capita income, at two reservoirs: the Barra Bonita (an eutrophic reservoir with some introduced species), and the Jurumirim (an oligotrophic reservoir, with no introduced species). Published data and structured interviews with fishers were used to evaluate fishing activity, fish biomass, and the financial performance of the fisheries. In the Barra Bonita Reservoir we analysed data from 745 fishing trips, from which $86,691.9 \mathrm{~kg}$ of fish were landed, with a mean CPUE of $62.4 \mathrm{~kg} / \mathrm{fisher}^{-1} \mathrm{day}^{-1}$. The main type of fish caught was tilapia (71,513.5 kg; CPUE of $51.5 \mathrm{~kg} /$ fisher $^{-1}$ day $\left.^{-1}\right)$, which constituted $82.5 \%$ of the biomass caught. In the Jurumirim Reservoir, we analysed data from 2,401 fishing trips, from which $25,093.6 \mathrm{~kg}$ of fish were landed, with a mean CPUE of $10.4 \mathrm{~kg} / \mathrm{fisher}^{-1} \mathrm{day}^{-1}$. The main type of fish caught was "traíra" $\left(6,158.6 \mathrm{~kg}\right.$; CPUE of $2.6 \mathrm{~kg} / \mathrm{fisher}^{-1}$ day $\left.^{-1}\right)$, which constituted $24.5 \%$ of the biomass caught. Ordination analysis (PCA) indicated that there was a difference in composition between the fishing reservoirs and ANCOVA showed that there was a significant difference in fish production between the reservoirs. A Student's $t$-test showed that fishers in the Barra Bonita Reservoir had a significantly higher gross per capita income than those from the Jurumirim Reservoir. Although the Barra Bonita Reservoir has a higher fish production and the fishers earn a higher gross per capita income, we recommend the Jurumirim Reservoir as a model for artisanal fishery management because fishing activity in this reservoir is viable in the long term and such a model would promote conservation and sustainability. This contrasts with the Barra Bonita Reservoir, in which the fishery is not viable in the long term, due to environmental problems caused by artificial eutrophication and the introduction of alien species. It is also noted that in many countries, management of fisheries based on exotic species has not been viable in the long term.

Nós comparamos a pesca artesanal, em termo de estratégia de captura, produtividade e renda per capita bruta em dois reservatórios: Barra Bonita (reservatório eutrófico e com espécies introduzidas) e Jurumirim (reservatório oligotrófico e sem espécies introduzidas). Dados publicados e entrevistas estruturadas mensais com os pescadores sobre a atividade de pesca, quilo pescado e rendimento financeiro, foram usados para as análises. No reservatório de Barra Bonita foram analisados dados de 745 viagens pesqueiras, que desembarcaram $86.691,9 \mathrm{~kg}$ de pescado, com CPUE de 62,4 kg/pescador ${ }^{-1}$ dia $^{-1}$. O principal pescado foi a tilápia $\left(71.513,5 \mathrm{~kg}\right.$, CPUE de $51,5 \mathrm{~kg} /$ pescador $\left.^{-1} \mathrm{dia}^{-1}\right)$ que representou $82,5 \%$ da biomassa pescada. No reservatório de Jurumirim analisamos dados de 2.401 viagens pesqueiras, que desembarcaram 25.093,6, como CPUE de 10, kg/ pescador ${ }^{-1} \mathrm{dia}^{-1}$. O principal pescado foi a traíra $\left(6.158,6 \mathrm{~kg}\right.$, CPUE de 2,6 $\left.\mathrm{kg}_{\text {pescador }} \mathrm{dia}^{-1}\right)$, que representou $24,5 \%$ da biomassa pescada. Uma análise de ordenação (PCA) indicou diferença na composição pesqueira entre os reservatórios e uma ANCOVA indicou diferença na produção pesqueira entre os reservatórios. Teste $t$ de Student foi significativo e os pescadores do reservatório de Barra Bonita tiveram maior renda per capita bruta. Embora o reservatório de Barra Bonita tenha tido maior produção pesqueira e os pescadores maior renda, recomendamos o reservatório de Jurumirim como modelo para gestão de pesca artesanal nos reservatório, pois a atividade mostrou ser viável em longo prazo bem como ecologicamente correto. Isto contrasta como o reservatório de Barra Bonita, em que a pesca não é viável em longo prazo, devido a problemas ambientais provocados pela eutrofização artificial e pela introdução de espécie. Observou-se que em muitos países, o manejo da pesca com espécies exóticas, não tem sido viável em longo prazo.

Key words: Barra Bonita Reservoir, Fish, Jurumirim Reservoir, Paranapanema River, Tietê River.

\footnotetext{
${ }^{1}$ Universidade Federal Rural do Semi-Árido - UFERSA, Departamento de Ciências Animais. Av. Francisco Mota, 572, Costa e Silva, 59625-900 Mossoró, RN, Brazil.novaes@ufersa.edu.br

${ }^{2}$ Universidade Estadual Paulista "Julio de Mesquita Filho"- UNESP, Departamento de Morfologia, Instituto de Biociências. Distrito de Rubião Jr., 18618-970 Botucatu, SP, Brazil. carvalho@ibb.unesp.br
} 


\section{Introduction}

Construction of hydroelectric dams and the consequent formation of reservoirs alters the natural hydrological regimes of river basins (Nilsson et al., 2005; Dudgeon et al., 2006) and causes changes in the species composition and community structure of fish assemblages (Lowe-McConnell, 1987; Petrere Jr., 1996). These changes directly affect fish stocks due to a general reduction in stocks of large migratory fish with high economic value, and a general increase in stocks of smalland medium-sized species with sedentary habits and low economic value (Hoeinghaus et al., 2009). The number of these artificial ecosystems is increasing for a number of reasons, including power generation and the provision of general water supplies, including irrigation. Consequently, reservoirs are becoming important environments for subsistence (artisanal) fishing (Jackson \& Marmulla, 2001) as a substitute for fisheries based on rivers and floodplains that have been destroyed due to construction of impoundments. Fishery products often supplement family incomes of low-income human communities living near reservoirs and, in many cases, provide the only source of animal protein (Beard et al., 2011), especially in developing countries (Sugunan, 2000; De Silva et al., 2004; Kester et al., 2007; Agostinho et al., 2008). Nevertheless, factors such as artificial eutrophication and the introduction of alien species are now threatening artisanal fishing activities in reservoirs (Agostinho et al., 2005; Allan et al., 2005).

Eutrophication of water bodies is a process caused by increased concentrations of nutrients, mainly phosphorus and nitrogen, which leads to increased productivity. It affects water bodies in many countries, especially in developing nations (Smith \& Schindler 2009). The main nutrients that cause eutrophication in reservoirs originate from agriculture, industry, mining, and domestic effluents. These nutrients have increased worldwide, due to rapid unplanned urban growth (Esteves \& Meirelles-Pereira, 2011). Eutrophication affects fish productivity and leads to changes in species composition, often resulting in a stock reduction of highly valued species and an increase in the stock of undesirable species with low economic value (Smith \& Schindler, 2009).

A number of species have been introduced into reservoirs in various parts of the world with the purpose of stocking desirable species, so as to restore fish production (Quirós \& Boveri, 1999). Between 1975 and 1989, the Companhia Energética de São Paulo was officially responsible for stocking reservoirs of the upper basin Paraná River (Brazil) with exotic species, including Plagioscion squamosissimus (native to the Amazon basin) and the African species Oreochromis niloticus, (Nile tilapia) (CESP, 1998). Other species, such as Cichla sp. (native to the Amazon basin), were stocked illegally in many reservoirs (Agostinho et al., 2007). Although exotic species can cause reductions in the stocks of native species and damage fisheries production (Agostinho et al., 2005; Pelicice \& Agostinho, 2009; Attayde et al., 2011) in some reservoirs, stocking with exotic species has resulted in increased fish production (Minte-Vera \& Petrere Jr., 2000; De Silva et al., 2004; Walter \& Petrere Jr., 2007).

The objective of the present study was to evaluate and compare the artisanal fisheries in two reservoirs of the upper basin of the Paraná River, the Barra Bonita Reservoir (Tietê River) and the Jurumirim Reservoir (Paranapanema River). The Barra Bonita reservoir is eutrophic and has been stocked with alien species, while the Jurumirim Reservoir is oligotrophic and has never been subjected to species introductions. Our evaluation was based on a comparison of fish production in quantitative terms, specifically catch per unit effort (CPUE), as well as qualitative measures and fishing strategies. In addition, we analysed the differences in terms of gross per capita income of the fishers in the two reservoirs.

\section{Material and Methods}

The Barra Bonita Reservoir (Tietê River, 22 31 '11.14'S and $048^{\circ} 32^{\prime} 05.12^{\prime \prime} \mathrm{W}$ ) and the Jurumirim Reservoir (Paranapanema River, 2312'36.02"S and 049¹3'49.07"W) are located in the upper Paraná River basin (Fig. 1). Morphometric and limnological characteristics of the reservoirs are presented in Table 1. The Barra Bonita Reservoir has been classified as hypertrophic since 2000, due to the significant amounts of untreated organic and inorganic effluents (estimated at approximately 130 tons/day) that are dumped into the Tietê River, the main tributary flowing through the metropolitan region of São Paulo (Tundisi et al., 2008), which flows for approximately $250 \mathrm{~km}$ from São Paulo to the Barra Bonita Reservoir. This stretch of river includes several small waterfalls and rapids that oxygenate the water, resulting in a slight improvement in water quality (Barrella \& Petrere Jr., 2003). Two other important tributaries of the Barra Bonita Reservoir, the Piracicaba and Sorocaba, which also receive large quantities of untreated domestic sewage, contribute to the hypertrophic state of the reservoir. Studies in the Barra Bonita Reservoir have recorded 39 species, with 10 introduced species (Petesse et al., 2007; Novaes \& Carvalho, 2011).

The Jurumirim Reservoir is located on the Paranapanema River and covers an area of $484.81 \mathrm{~km}^{2}$. From its source to its mouth at the Jurumirim Reservoir, the Paranapanema River passes through a less populated and less industrialised region, than is the case for the Tiete River. The banks of the Paranapaenma River are well preserved with retention of riparian forests, and many oxbow lakes alongside the main river channel (Henry et al., 2006). A recent study classified the Jurumirim Reservoir as oligotrophic (Nogueira et al., 2010). The 42 species of fish recorded from this reservoir includes only one introduced species, Cyprinus carpio, of which only one specimen has been captured (Carvalho et al., 2003).

In this study we compared data on artisanal fisheries (from Novaes \& Carvalho, 2009; and Novaes \& Carvalho, 2011) from the Jurumirim and Barra Bonita reservoirs. The following data on the fisheries in both reservoirs were obtained: information on catches (composition and biomass of fish in kilograms), effort (number of fishers) and fishing strategies. 


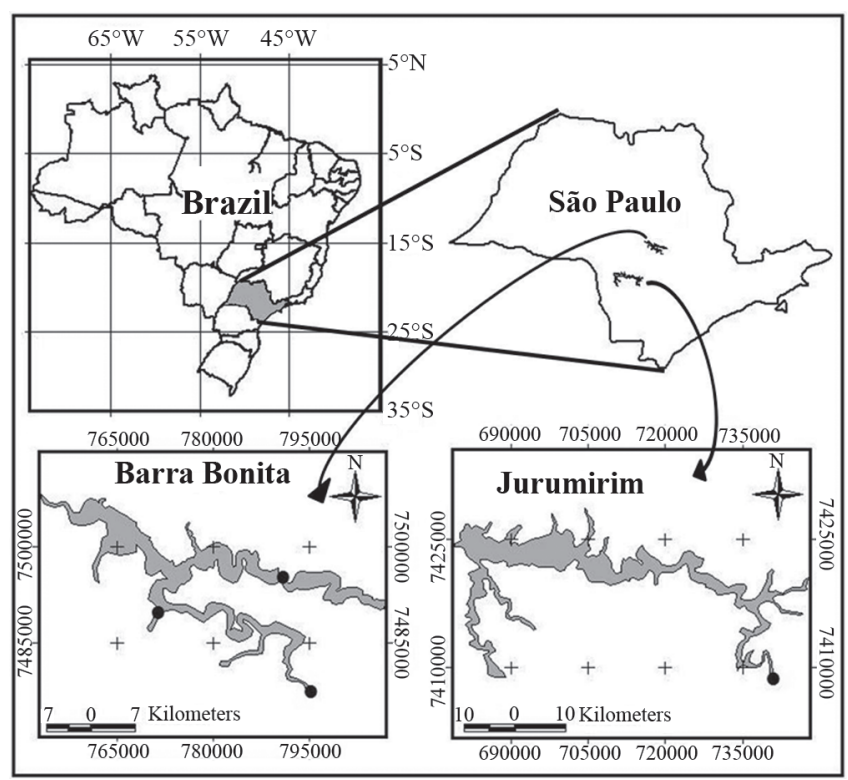

Fig. 1. Location of the Barra Bonita Reservoir and the Jurumirim Reservoir with sampling sites (black circles).

In the Barra Bonita Reservoir sampling was undertaken between July 2004 and June 2006 at three landing sites (Fig. 1) and the artisanal fishers at these sites operated throughout the reservoir (David et al., 2006). We initially attempted to organise a voluntary system for the use of fishers when completing our survey form, but this system was unsuccessful. Instead we adopted a sampling system in which an observer visited three sampling sites once a month to interview fishers. In the Jurumirim Reservoir, sampling was carried out between January 2005 and December 2006 at the "Bairro da Ponte" fishing colony, at the site where the Paranapanema River enters the Jurumirim Reservoir (Fig. 1). The artisanal fishers in the Jurumirim Reservoir operate only in the transition region between the Paranapanema River and the reservoir, constituting an area of 800 ha (Carvalho \& Silva, 1999). We established a partnership with a data collector (a trusted local community leader) who made use of a standardised survey system to record information pertaining to each fisher, on a daily basis. The completed surveys were collected and checked by the investigators and the data collector monthly. The prices charged for each type of fish and the income of the fishers were obtained using a standardised survey with 243 fishers in Barra Bonita Reservoir and 24 fishers in Jurumirim Reservoir.

For qualitative analysis, the samples of caught fish were collected for identification in the laboratory using taxonomic keys (Britski, 1972; Britski et al., 1999). For quantitative analysis, the fish were grouped in the same way as when sold by the fishers. Fishery production data was expressed as $\mathrm{kg} /$ fisher ${ }^{1}$ day $^{-1}$. Data on the capture and landing of "piquira", a local name that represents a variety of small fish Chraciformes (Castro et al., 2003), were considered separately because a unique
Table 1. Barra Bonita Reservoir and Jurumirim Reservoir: morphometric, geographical, and limnological (annual average for reservoirs) features. For Barra Bonita Reservoir, according to Tundisi et al. (2008), and for Jurumirim Reservoir, according to Nogueira et al. (2010).

\begin{tabular}{lcc}
\hline Feature & $\begin{array}{c}\text { Barra Bonita } \\
\text { Reservoir }\end{array}$ & $\begin{array}{c}\text { Jurumirim } \\
\text { Reservoir }\end{array}$ \\
\hline Year of formation & 1963 & 1962 \\
Area & $325 \mathrm{~km}^{2}$ & $484 \mathrm{~km}^{2}$ \\
Volume & $3.6 \times 10^{6} \mathrm{~m}^{3}$ & $7.9 \times 10^{9} \mathrm{~m}^{3}$ \\
Geographic coordinates & $22^{\circ} 31^{\prime} \mathrm{S} 48^{\circ} 32^{\prime} \mathrm{W}$ & $23^{\circ} 12^{\prime} \mathrm{S} 49^{\circ} 13^{\prime} \mathrm{W}$ \\
Mean depth & $10.0 \mathrm{~m}$ & $12.90 \mathrm{~m}$ \\
Residence time of water & 100 days & 334 days \\
Perimeter & $525.0 \mathrm{~km}$ & $1,115.0 \mathrm{~km}$ \\
Mean precipitation (Annual) & $1,300-1,500 \mathrm{~mm}^{3}$ & $1,300-1,500 \mathrm{~mm}^{3}$ \\
Climate & Tropical humid & Tropical humid \\
Dissolved $\mathrm{O}_{2}$ & $5.0 \mathrm{mg} . \mathrm{L}$ & $5.6 \mathrm{mg} . \mathrm{L}$ \\
pH & 6.7 & 5.8 \\
Surface water temperature & $24.6^{\circ} \mathrm{C}$ & $21.5^{\circ} \mathrm{C}$ \\
Conductivity & $333.0 \mu \mathrm{S} . \mathrm{cm}$ & $91.3 \mu \mathrm{s} . \mathrm{cm}$ \\
Total nitrogen & $3,479.6 \mu \mathrm{g} . \mathrm{L}$ & $517.05 \mu \mathrm{g} . \mathrm{L}$ \\
Total phosphorus & $40.1 \mu \mathrm{g} . \mathrm{L}$ & $23.8 \mu \mathrm{g} . \mathrm{L}$ \\
Chlorophyll $a$ & $42.57 \mu \mathrm{g} . \mathrm{L}$ & $4.1 \mu \mathrm{g} . \mathrm{L}$ \\
Trophic state & Hypereutrophic & Oligotrophic \\
\hline
\end{tabular}

capture technique was applied for these fish in which several family members were involved in the fishing activity, making it difficult to quantify the fishing effort used. Voucher specimens were deposited in the Laboratório de Biologia e Genética de Peixes (LBP), Instituto de Biociências, Universidade Estadual Paulista - câmpus Botucatu, under identification number LBP 9167 to LBP 9207 and LBP 13298 to LBP 13320.

The estimation of gross per capita income of the fishers was based on the financial value of each type of fish reported by the fishers in the surveys. The average price for each type of fish was also ascertained from the fishers. The values were reported in Reais (Brazilian currency) by the fishers and converted to U.S. dollars at a rate of US $\$ 1.00=\mathrm{R} \$ 1.90$.

Only the data from 2005, which were collected simultaneously from both reservoirs, were used for statistical analysis. To test for differences in the composition of the fish caught from the reservoirs (data $\log _{10}$ transformed), we used a principal component analysis (PCA) derived by using a correlation matrix for the monthly CPUE data for each type of fish caught at the two reservoirs. The first two PCA axes were used to interpret the results. To test if there was a difference in catch between the reservoirs, an Analysis of Covariance (ANCOVA) was applied, where $\log _{10}$ of catch was the response variable, the reservoirs were categorical variables, and $\log _{10}$ of fishing effort (expressed as fishers per day) was the covariate. The residuals were tested for normality $(\mathrm{g} 1=$ asymmetry coefficient and g2 = coefficient of kurtosis) to validate the ANCOVA model by visually inspecting the plotted values to determine if there was a tendency towards nonlinearity.

A Student's t-test $(\mathrm{p}<0.05)$ was used to compare the net income of the fishers from the two reservoirs; $\mathrm{H}_{0}$ represented 
equal incomes of the fishers from the two reservoirs, and $\mathrm{H}_{1}$ represented a difference in the incomes of the fishers from the two reservoirs. Prior to performing the t-test, the normality and homogeneity of variance of the $\log _{10}$ transformed data were tested using Kolmogorov-Smirnov and Bartlett tests, respectively.

Statistical analyses were performed using Statistica 8.0 software.

\section{Results}

We recorded 33 species landed by fishers in the Barra Bonita Reservoir, eight of which were introduced species. In the landings from the Jurumirim Reservoir, we recorded 31 species caught by fishers. There were no records of introduced species from the latter reservoir (Table 2).

Data from the Barra Bonita Reservoir were obtained from 745 fishing trips, with a total of $86,691.9 \mathrm{~kg}$ of fish landed, representing an average production of $116.3 \mathrm{~kg} / \mathrm{trip}^{-1}(\mathrm{SD} \pm 107.1)$ and a mean CPUE of $62.4 \mathrm{~kg} /$ fisher $^{-1} \mathrm{day}^{-1}(\mathrm{SD} \pm 55.5)$. The exotic "tilapias" Oreochromis niloticus and Tilapia rendalii represented $82.5 \%$ of the fish biomass landed, corresponding to $71,513.5 \mathrm{~kg}$ and $51.5 \mathrm{~kg} /$ fisher $^{-1}$ day $^{-1}$ (however O. niloticus represented $98 \%$ of the tilapia landed). Other important fish caught in the Barra Bonita Reservoir were the "cascudos", "mandi", "sardinha", and "curimbatá". These five types of fish (in which the two "tilapia" species are regarded as a single 'type') accounted for $97.6 \%$ of the fish biomass landed (Table 3). The Jurumirim Reservoir data were obtained from 2,401 fishing trips, which landed 25,093.6 kg of fish, indicating a mean production of $10.5 \mathrm{~kg} / \mathrm{trip}^{-1}(\mathrm{SD} \pm 6.9)$. In this reservoir, each boat was used by just one fisherman, and thus the average CPUE was $10.5 \mathrm{~kg} /$ fisher $^{-1} \mathrm{day}^{-1}(\mathrm{SD} \pm 6.9)$. The main fish landed in terms of biomass in the Jurumirim Reservoir was the "traíra" $\left(6,158.6 \mathrm{~kg}, 2.6 / \mathrm{kg}\right.$ fisher $\left.{ }^{-1} \mathrm{day}^{-1}, 24.5 \%\right)$, that, together with the piava, curimbatá, piranha and mandi, accounted for $81.0 \%$ of the total fish biomass landed (Table 3). The "piquira", a group of small fish Characiformes caught with a particular capture technique involving several family members (described below), constituted an important source of income for fishers in the Jurumirim Reservoir. In the present study, the landed "piquiras" represented an average productivity of 1.5 tons/year.

The first two PCA axes explained $86.89 \%$ (axis $1=67.36 \%$; eigenvalue $=27.61$ and axis $2=19.53 \%$; eigenvalue $=8.0$ ) of the variation in catches and showed a clear separation in the composition of the fish caught between the two reservoirs (Fig. 2). There were no problems with the assumptions that were used for the ANCOVA. The results of the ANCOVA indicated a significant effect of the covariate (effort) $(\mathrm{F}=263.0$; $\mathrm{p}$-value $<0.000 ; \mathrm{p}<0.05$ ) and reservoir ( $\mathrm{F}=17.9 ; \mathrm{p}$-value $<0.000$; $\mathrm{p}<0.05$ ), indicating differences in productivity between reservoirs, with the Barra Bonita reservoir having the higher productivity. The interaction was not significant $(\mathrm{F}=1.7$; $\mathrm{p}-$ value $=0.193 ; \mathrm{p}<0.05)$.

Six fishing techniques were used by the artisanal fishers surveyed in the two reservoirs: beach seine, cast nets, beating gill nets (active techniques), gill nets, and traps - which consisted of lift nets operated in shores (passive techniques), and a combination of gill nets and beating gill nets. Of these six fishing techniques, five were used by fishers in the Barra Bonita Reservoir. Beach seine was the favoured technique used by most fishers in the Barra Bonita Reservoir, which was reportedly used in 232 (31.14\%) fishing trips. Two capture techniques were used in the Jurumirim Reservoir: gill nets, recorded in all trips, and traps (Table 4). This latter technique involved the participation of several members of the fisherman's family and was practiced separately from normal fishing activities. This made it impossible to determine the number of trips on which this technique was used.

The fish caught in the Jurumirim Reservoir attained higher prices for fishers than those caught from the Barra Bonita Reservoir. The most valuable fish in the Jurumirim Reservoir were the fish in the "piquira" group, with an average price per kilo of $\$ 1.65$. The most valuable fish caught in the Barra Bonita Reservoir were "cascudo" and "tilapia", which attained an average price per kilogram of $\$ 0.97$ and $\$ 0.69$, respectively (Table 5). A direct comparison of the prices of fish caught from the two reservoirs indicated that the fish from Jurumirim were more valuable. The fishers of the Barra Bonita Reservoir (\$26.36) earned more than those of the Jurumirim Reservoir (\$18.85). The average daily gross per capita income of the fishers also differed between the reservoirs $(t=2.0 ; \mathrm{p}<0.05$; p-value $<0.05$ ).

\section{Discussion}

The productivity and composition of the fish caught differed between the two reservoirs. The Barra Bonita Reservoir showed relatively high fish productivity, due to the exotic species $O$. niloticus, and is among the most productive in Brazil, with its productivity levels being comparable to reservoirs with similar characteristics, i.e., eutrophic reservoirs that contain the exotic species $O$. niloticus (Paiva et al., 1994; Alvares et al., 2000; Minte-Vera \& Petrere Jr., 2000; Walter \& Petrere Jr., 2007). High fish productivity has been noted in eutrophic reservoirs of other countries that contain introduced "tilapia" species (Averhoff, 1999; Nissanka et al., 2000; Sugunan, 2000; Jackson \& Marmulla, 2001; Amarisinghe, 2002; Kester et al., 2007; Caraballo, 2009). Exotic species have become successfully established in eutrophic freshwater reservoir ecosystems around the world (Smith \& Schindler, 2009; Wolos et al., 2009; La Porta et al., 2010; Morosawa, 2011). Thus, it seems likely that the high fishery productivity in the Barra Bonita Reservoir is associated with a high primary production and the presence of an introduced species adapted to lentic conditions. Other characteristics associated with high reproductive potential such as multiple spawning per year, extended reproductive periods, parental care, the ability to feed on plankton present in reservoirs, tolerance to low oxygen concentrations and low predation pressure - are factors that might explain the successful establishment of $O$. niloticus in reservoirs in Brazil 
Table 2. List of fish species caught by artisanal fisheries in the Barra Bonita (Tietê River) and Jurumirim (Parnapanema River) reservoirs during the study period. ${ }^{a}$ Non-native species.

\begin{tabular}{|c|c|c|c|}
\hline Taxon & Common name & $\begin{array}{c}\text { Barra Bonita } \\
\text { Reservoir }\end{array}$ & $\begin{array}{c}\text { Jurumirim } \\
\text { Reservoir }\end{array}$ \\
\hline \multicolumn{4}{|l|}{ CHARACIFORMES } \\
\hline \multicolumn{4}{|l|}{ Anostomidae } \\
\hline Leporinus friderici (Bloch, 1974) & Piava, piau & $\mathrm{X}$ & $\mathrm{X}$ \\
\hline Leporinus obtusidens (Valenciennes, 1837) & Piava, piau & $\mathrm{X}$ & $\mathrm{X}$ \\
\hline Leporinus elongatus Valenciennes, 1850 & Piava, piau & $\mathrm{X}$ & \\
\hline Leporinus octofasciatus Steindacher, 1915 & Piava, piau & & $\mathrm{X}$ \\
\hline Schizodon intermedius Garavello \& Britski, 1990 & Piapara, ximboré & $\mathrm{X}$ & $\mathrm{X}$ \\
\hline Schizodon nasutus Kner, 1858 & Piapara, ximboré & & $\mathrm{X}$ \\
\hline \multicolumn{4}{|l|}{ Characidae } \\
\hline Astyanax altiparanae Garutti \& Britski, 2000 & Lambari & $\mathrm{X}$ & $\mathrm{X}$ \\
\hline Astyanax fasciatus (Cuvier, 1819) & Lambari & $\mathrm{X}$ & $\mathrm{X}$ \\
\hline \multicolumn{4}{|l|}{ Bryconamericus iheringi (Boulenger, 1887) } \\
\hline Bryconamericus stramineus Eigenmann, 1908 & Piquira & & $\mathrm{X}$ \\
\hline Bryconamericus sp. & Piquira & & $\mathrm{X}$ \\
\hline Cheirodon stenodon (Eigenmann, 1915) & Piquira & & $\mathrm{X}$ \\
\hline Galeocharax knerii (Steindachner, 1879) & Cadela & $\mathrm{X}$ & $\mathrm{X}$ \\
\hline Odontostilbe sp. & Piquira & & $\mathrm{X}$ \\
\hline Salminus brasiliensis (Cuvier, 1816) & Dourado & $\mathrm{X}$ & \\
\hline Salminus hilarii Valenciennes, 1850 & Tabarana & $\mathrm{X}$ & $\mathrm{X}$ \\
\hline Serrapinnnus notomelas (Eigenmann, 1915) & Piquira & & $\mathrm{X}$ \\
\hline Triportheus nematurus ${ }^{\mathrm{a}}$ (Kner, 1858) & Sardinha, sardela & $\mathrm{X}$ & \\
\hline \multicolumn{4}{|l|}{ Serrasalmidae } \\
\hline Piaractus mesopotamicus (Holmberg, 1887) & Pacu & $\mathrm{X}$ & $\mathrm{X}$ \\
\hline Serrasalmus maculatus Kner, 1858 & Piranha & $\mathrm{X}$ & $X$ \\
\hline \multicolumn{4}{|l|}{ Parodontidae } \\
\hline Apereiodon affinis & Bicudinho & & $\mathrm{X}$ \\
\hline Apareiodon piracicabae (Eigenmann, 1907) & Canivete & $\mathrm{X}$ & $\mathrm{X}$ \\
\hline \multicolumn{4}{|l|}{ Curimatidae } \\
\hline Cyphocharax modestus (Fernández-Yépez, 1948) & Lambari & $\mathrm{X}$ & $\mathrm{X}$ \\
\hline Steindachnerina insculpta (Fernández-Yépez, 1948) & Lambari & $\mathrm{X}$ & $\mathrm{X}$ \\
\hline \multicolumn{4}{|l|}{ Erythrinidae } \\
\hline Hoplias malabaricus (Bloch, 1794) & Traíra & $\mathrm{X}$ & $\mathrm{X}$ \\
\hline \multicolumn{4}{|l|}{ Prochilodontidae } \\
\hline Prochilodus lineatus (Valenciennes, 1836) & Curimatá & $\mathrm{X}$ & $\mathrm{X}$ \\
\hline \multicolumn{4}{|l|}{ SILURIFORMES } \\
\hline \multicolumn{4}{|l|}{ Callichthyidae } \\
\hline Hoplosternum littorale (Hancock, 1828) & Caborja & $\mathrm{X}$ & $\mathrm{X}$ \\
\hline \multicolumn{4}{|l|}{ Loricariidae } \\
\hline Hypostomus spp. & Cascudo & $\mathrm{X}$ & $\mathrm{X}$ \\
\hline Hypostomus ragani (Ihering, 1905) & & & $\mathrm{X}$ \\
\hline Pterygoplichthys ambrosetti (Eigenmann \& Kennedy, 1903) & Cascudo & $\mathrm{X}$ & \\
\hline \multicolumn{4}{|l|}{ Heptapteridae } \\
\hline Rhamdia quelen & Bagre & & $\mathrm{X}$ \\
\hline Pimelodidae & & & \\
\hline Iheringichthys labrosus & Mandiuvinha & & $\mathrm{X}$ \\
\hline Pimelodus maculatus Lacepède, 1803 & Mandi & $\mathrm{X}$ & $\mathrm{X}$ \\
\hline Doradidae & & & \\
\hline Rhinodoras cf. dorbignyi (Kner, 1855) & & $\mathrm{X}$ & \\
\hline GYMNOTIFORMES & & & \\
\hline Gymnotidae & & & \\
\hline Eigenmannia sp. & Tuvira & $\mathrm{X}$ & \\
\hline Gymnotus inaequilabiatus (Valenciennes, 1839) & Tuvira & $\mathrm{X}$ & \\
\hline Gymnotus sylvius Albert \& Fernandes-Martioli, 1999 & Tuvira & & $\mathrm{X}$ \\
\hline PERCIFORMES & & & \\
\hline Cichlidae & & & \\
\hline Astronotus ocellatus $^{\mathrm{a}}$ (Agassiz, 1831) & Oscar & $\mathrm{X}$ & \\
\hline Crenicichla sp. & Joaninha & $\mathrm{X}$ & \\
\hline Geophagus brasiliensis (Quoy \& Gaimard, 1824) & Cará & $\mathrm{X}$ & $\mathrm{X}$ \\
\hline Oreochromis niloticus ${ }^{\mathrm{a}}$ (Linnaeus, 1758) & Nile tilapia & $\mathrm{X}$ & \\
\hline Satanoperca pappaterra (Heckel, 1840) & Cará & $\mathrm{X}$ & \\
\hline Tilapia rendalli ${ }^{\mathrm{a}}$ (Boulenger, 1897) & Tilápia & $\mathrm{X}$ & \\
\hline Sciaenidae & & & \\
\hline Plagioscion squamosissimus ${ }^{\mathrm{a}}$ (Heckel, 1840) & Corvina, pescada & $\mathrm{X}$ & \\
\hline CYPRINIFORMES & & & \\
\hline Cyprinidae & & & \\
\hline Hypophthalmichthys molitrix ${ }^{\mathrm{a}}$ (Valenciennes, 1844) & Carpa cabeça grande & $\mathrm{X}$ & \\
\hline Hypophthalmichthys nobilis ${ }^{\mathrm{a}}$ (Richardson, 1845) & Carpa & $\mathrm{X}$ & \\
\hline
\end{tabular}


Table 3. Total biomass $(\mathrm{kg})$, relative frequency $(\%)$, and CPUE $\left(\mathrm{kg} \mathrm{fisher}^{-1}\right.$ day $\left.^{-1}\right)$ for the main fish caught of artisanal fisheries in the Barra Bonita and Jurumirim Reservoirs during the study period. * = captured only in Barra Bonita Reservoir.

\begin{tabular}{cccccccc}
\hline \multirow{2}{*}{ Fish } & Species & \multicolumn{3}{c}{ Barra Bonita Reservoir } & \multicolumn{3}{c}{ Jurumirim Reservoir } \\
\cline { 2 - 7 } & & Total biomass & $\%$ & CPUE (SD) & Total biomass & $\%$ & CPUE (SD) \\
\hline Tilapia & O. niloticus and T.rendalli & $71,513.5$ & 82.5 & $51.5(54.3)$ & - & - & - \\
Cascudo & P.ambrosettii* and Hypostomus spp. & $6,151.6$ & 7.1 & $4.4(16.1)$ & - & - \\
Curimbatá & P. lineatus & $1,650.6$ & 1.9 & $1.2(4.7)$ & $4,409.0$ & 17.6 & $1.8(3.5)$ \\
Mandi & P.maculatus & $3,020.3$ & 3.5 & $2.2(7.5)$ & $2,018.5$ & 8.0 & $0.9(2.1)$ \\
Sardinha & T.nematurus & $2,214.7$ & 2.6 & $1.6(10.3)$ & - & - & - \\
Traíra & H.malabaricus & 369.4 & 0.4 & $0.5(1.6)$ & $6,158,5$ & 24.5 & $2,6(3.3)$ \\
Piau & L. friderici, L. obtusidens and L. elongatus & - & - & - & $5,541.5$ & 22.1 & $2.3(2.9)$ \\
Piranha & S. maculatus & - & - & - & $2,133.0$ & 8.5 & $0.8(1.7)$ \\
Outros & Other species & $1,771.9$ & 2.0 & $1.0(3.5)$ & $4,852.1$ & 19.3 & $2.0(3.9)$ \\
Total & & $86,691.9$ & 100 & $62.4(55.4)$ & $25,112.6$ & 100 & $10.5(6.9)$ \\
\hline
\end{tabular}

and worldwide (Duponchelle et al., 2000; Fernando \& Holèík, 1991; Minte-Vera \& Petrere Jr., 2000). Thus, in addition to the eutrophic reservoir conditions, it is likely that the abovementioned characteristics have contributed to the establishment, proliferation, and dominance of this species in the fishery landings in the Barra Bonita Reservoir.

The fishery productivity in the Jurumirim Reservoir was lower than that of the Barra Bonita Reservoir and was comparable to that of other non-eutrophic Brazilian reservoirs and some eutrophic reservoirs that do not contain the exotic O. niloticus (Okada et al., 1997; CESP, 1998; ECO - AES Tietê, 2001; Franco de Camargo \& Petrere Jr., 2004; Sato \& Sampaio, 2006; Agostinho et al., 2008). Nevertheless, the community of fish harvested at the Jurumirim Reservoir was more diverse, included migratory fish species, and the dominance of particular species was lower. No introduced species were recorded at Jurumirim. According to Novaes \&

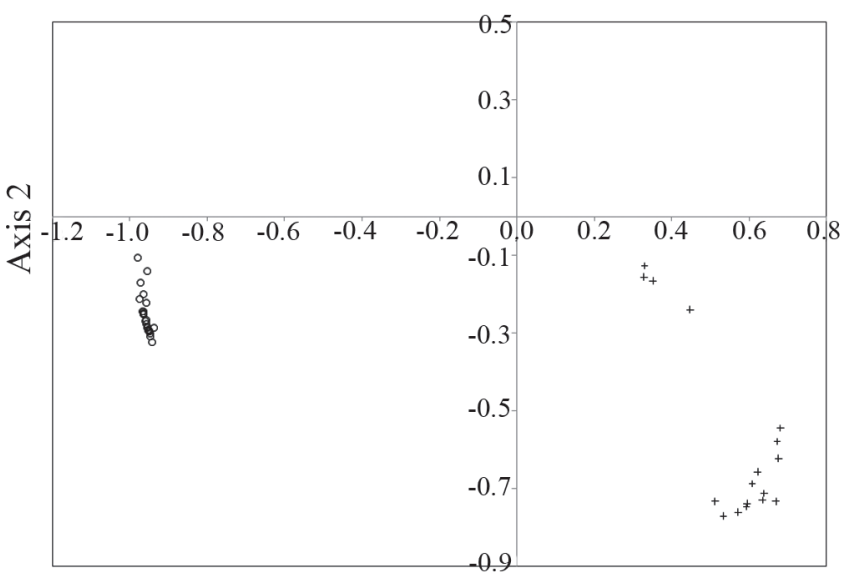

Axis 1

Fig. 2. Scores of the first two axes derived via principal component analysis (PCA), which analysed CPUE data on fish captured by the artisanal fisheries in the two reservoirs during the study period. cross $=$ Jurumirim Reservoir; circle $=$ Barra Bonita Reservoir.
Carvalho (2011) several hypotheses can be put forward to explain these qualitative and quantitative results: i) the region exhibits good environmental quality; ii) the region is characterised by tributaries, such as the Santa Helena and Guareí Rivers, and upstream stretches of the Paranapanema River, that retain relatively well-preserved fish habitat; iii) the lagoons and small marginal lakes along the Paranapanema River are of great importance and provide shelter and food required for the development of fish larvae and juveniles (Godoy, 1975); iv) high habitat heterogeneity, including lotic and lentic environments, marginal lakes, floodplains, and refuges for small fish (e.g., macrophytes), as well as the presence of preserved tributaries, are factors that increase fish species diversity. The capture of "piquiri" (small species from basal trophic guilds) was also an indicator of good environmental conditions in the region, such as favourable water quality, well-preserved riparian vegetation, and the presence of aquatic macrophytes (Castro et al., 2003). In addition, we found no information in the literature about tilapia stocking in the Jurumirim Reservoir.

It should also be noted that the fishing activities at the Jurumirim Reservoir are focused around the transitional areas between the reservoir and its tributaries. These regions are typically more productive, exhibit greater species diversity, and have the highest concentrations of migratory fish species (Okada et al., 2005) in comparison with conditions in the Barra Bonita Reservoir. Smaller migratory fish species, such as Pimelodus maculatus and Prochilodus lineatus, which were well represented in catches from the Jurumirim Reservoir, can maintain viable stocks if the reservoirs maintain the necessary conditions for their reproduction and recruitment of juveniles. The required conditions for these species include an upstream region that has not been impounded, the maintenance of flood pulse dynamics, and the presence of well-preserved tributaries, marginal lakes, and riparian vegetation (Silvano \& Begossi, 2001; Gubiani et al., 2007). These conditions are found in the Jurumirim Reservoir. It should be noted, however, that $P$. maculatus and P. lineatus are species with a lower economic value than the larger-bodied migratory species (Hoeinghaus et al., 2009). 
Table 4. Number (N) and frequency (\%) of the use of capture techniques during fishing trips in the Barra Bonita and

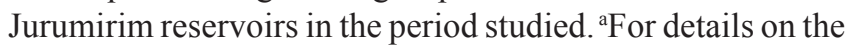
use of capture techniques, see Novaes \& Carvalho (2009,

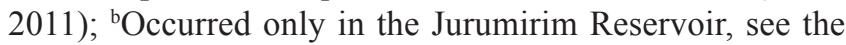
explanation in the text

\begin{tabular}{lcccc}
\hline Reservoir & \multicolumn{2}{c}{ Barra Bonita Reservoir } & \multicolumn{2}{c}{ Jurumirim Reservoir } \\
\hline Capture techniques $^{\mathrm{a}}$ & $\mathrm{N}$ & $\%$ & $\mathrm{~N}$ & $\%$ \\
\hline Beating gill net & 88 & 11.81 & - & - \\
Cast net & 99 & 13.29 & - & - \\
Gill net & 163 & 21.88 & 2,401 & 100 \\
Gill net/ beating gill net & 163 & 21.88 & - & - \\
Trap $^{\mathrm{b}}$ & - & - & & \\
Beach seine & 232 & 31.14 & - & - \\
\hline
\end{tabular}

At the Barra Bonita Reservoir, most fishers used active capture techniques, targeting the Nile tilapia. Among the active capture techniques employed, cast nets and beating gill nets have been successfully used to capture Nile tilapia in other Brazilian reservoirs (Câmara et al., 1998; Minte-Vera \& Petrere Jr., 2000; Walter \& Petrere Jr., 2007). Other active capture techniques used by fishers include the beach seine technique, which has also been used to successfully capture Nile tilapia (Novaes \& Carvalho, 2011). This technique was used in the lentic region of the reservoir where the characteristics of the environment - such as shallow borders, fewer submerged trees, and marginal areas where fishers can retrieve nets and collect fish - favour its use. A combination of gill nets and beating gill fishing was used by the fishers of Barra Bonita Reservoir to maximise their catches. Fishers set their gill nets overnight to capture Nile tilapia, "cascudo" and "curimbatá". After checking their gill nets in the morning, the fishers use the beat fishing technique to catch Nile tilapia. The use of gill nets was the only technique used in both the Barra Bonita and the Jurumirim Reservoirs. This technique has also been successfully used by fishers from other Brazilian reservoirs, to capture "mandi" (Pimelodus spp.) and "curimbatá" (Prochilodus lineatus) (Castro \& Begossi, 1995; Agostinho et al., 2007). In the Barra Bonita Reservoir this technique was used mainly to capture "sardinha", "mandi", "traíra", and small species known locally as "lambaris" (Astyanax spp.) and "saguirú" (Cyphocarax modestus and Sreindachnerina insculpta). Traps were used only in the Jurumirim Reservoir, to catch a group of fish known locally as "piquira". The technique was found to represent an important source of income for local fishers and has cultural significance for residents, who hold an annual traditional "piquira" party. Among the fishing techniques identified in the two reservoirs, only gill nets and cast nets are permitted by Brazilian legislation (Instrução do Ministro do Meio Ambiente $\mathrm{N}^{\circ} 262009$ ). It was noted that fishing activities continued during the reproductive season of some fish species, in spite of prohibitions on fishing activities, particularly in the Barra Bonita Reservoir.

In the region around the Jurumirim Reservoir, the fish prices were higher than those in the Barra Bonita Reservoir
Table 5. Price of fish in the Barra Bonita and Jurumirim reservoirs. "a"Porquinho" processing consists of removing the dorsal and anal fins, head, viscera, and sometimes the scales and epidermis.

\begin{tabular}{lcc}
\hline Fish & $\begin{array}{c}\text { Barra Bonita Reservoir } \\
\text { (US\$) }\end{array}$ & $\begin{array}{c}\text { Jurumirim Reservoir } \\
\text { (US\$) }\end{array}$ \\
\hline Tilapia & & \\
Non eviscerated & 0.42 & - \\
Porquinho $^{\mathrm{a}}$ & 0.69 & - \\
Curimbatá & 0.39 & 1.53 \\
Cascudo & & \\
Fillet & 0.97 & - \\
Traíra & 0.61 & 1.53 \\
Mandi & 0.55 & 1.53 \\
Corvina & 0.55 & - \\
Lambari & 0.50 & 1.10 \\
Sardella & 0.30 & - \\
Piquira & - & 1.65 \\
Piau & - & 1.53 \\
Piranha & - & 0.65 \\
Others & 0.30 & 0.85 \\
\hline
\end{tabular}

region. Two factors may have influenced the price: the local sale of fish, and environmental differences between the two reservoirs. Almost all fish near the Barra Bonita Reservoir is sold in the metropolitan region of São Paulo city, where the supply of fish is high and, consequently, the price of the product decreases. On the other hand, fish in the Jurumirim Reservoir region is sold in cities near the reservoir, where the supply of fish is low and, consequently, the price increases. With respect to environmental issues, in Finland, for example, eutrophic lakes are generally associated with a devaluation of fish prices and exotic species also have a low market value (Tammi et al., 1999). A similar finding was reported in northeast Brazil (Attayde et al., 2011). However, the gross per capita income of fishers at the Barra Bonita Reservoir was significantly higher than that of the fishers at Jurumirim, which was probably caused by the high productivity of Nile tilapia in the Barra Bonita Reservoir. The increased biomass of fish caught in the Barra Bonita Reservoir therefore offsets the lower price of the fish in the area close to reservoir and generates a higher income for fishers. The Barra Bonita and Jurumirim Reservoirs are among the most profitable Brazilian reservoirs for fishers. In the case of the Barra Bonita Reservoir, the high profits relates to the high productivity of the reservoir. At the Jurumirim Reservoir, two hypotheses have been suggested to explain the high profits: i) the environmental status of the region is good, which means that the aquatic environments would provide a variety of habitats in which fishers can operate (river, transitional environments, and oxbow lakes). This variety facilitates the capture of more valuable species and a more diverse harvest, which generates more market options; ii) fisheries sustained by native species, which are more acceptable to consumers, have greater economic value.

Despite the high productivity of the Barra Bonita Reservoir and other reservoirs with similar characteristics (i.e., 
eutrophic reservoirs containing the exotic $O$. niloticus) and the greater per capita income of fishers at this site, we believe that fishing in eutrophic ecosystems, based on the capture of introduced species, is not economically sustainable in the long term, for a number of reasons. Firstly, dependence on a single species is inherently risky since the productivity of the reservoir would be drastically reduced, should the stocks collapse. Secondly, even though $O$. niloticus tolerates the inhospitable conditions associated with an eutrophic environment, its physiological tolerance to these conditions has limits. Furthermore, achieving environmental recovery of these ecosystems in the short and medium term, to reduce the effects of eutrophication, is a difficult task. Thirdly, although exotic species may experience rapid population growth soon after their introduction, their long-term establishment is uncertain, due to biotic and abiotic factors that can cause population declines.

Reservoirs in which artisanal fisheries dependent on a single stock (for example, O. niloticus) are only found in Southeast Asia, in reservoirs that have been massively stocked (De Silva et al., 2004). A number of research projects have indicated that, in Brazil and in other countries, the fish catch has shown declines several years after the introduction of such species (Tammi et al., 1999; ECO - AES Tietê, 2001; Wolos et al., 2009; Attayde et al., 2011; Han \& Dumont 2011). The negative impacts of species introductions on native species, as well as the association between the tilapia and eutrophication, has been demonstrated in many studies (including Starling et al., 2002; Figueredo \& Giani, 2005; Attayde et al., 2007). Such impacts result in a general increased vulnerability of ecosystems and decreased options in terms of fishing. For these reasons, we are not in favour of management policies for protecting introduced species, which are currently applied in the Barra Bonita Reservoir and are at odds with the appropriate maintenance of aquatic resources. In recent years, certain measures have, however, been adopted to protect fisheries that are based on indigenous species. The "tilapia" fishery has been interrupted during the closed season, between November and February, with the aim of protecting migratory and native species during their reproductive period. There are, however, certain recommendations to lift current regulations to protect "tilapia" by means of banning the use of certain fishing techniques. Such regulations have been strongly criticised by environmental monitors. From an ecological perspective, the removal of tilapia would be the most appropriate course of action for the management of aquatic resources. It is felt that, as a matter of ecological principle, conservation efforts should not be directed towards non-native species (Agostinho et al., 2007).

Our results suggest that the Jurumirim Reservoir, and other well-preserved upstream areas, have the potential to maintain an artisanal fishery supported by native and migratory species with good market value. We therefore encourage managers to adopt management strategies aimed at improving the environmental conditions found in the Jurumirim Reservoir and its surroundings, including preserving water quality, encouraging the preservation of marginal lakes and riparian vegetation, and discouraging the introduction, and continued support, of introduced species. The conservation of well-preserved tributaries and upstream areas of the Paranapanema River, that are in good condition and free of blockages, should also be encouraged. Such ecosystem characteristics are essential for the completion of the life cycle of a number of native species. This would enhance the economic viability of the fishery and benefit fishers that use resources in the reservoir. These fishers generally have a low level of education, and fishing is one of few economic alternatives available. It should be emphasised that this fishing colony has existed since the formation of the Jurumirim Reservoir in 1962, and fishing has always been the main source of income for its residents (Novaes \& Carvalho, 2009).

We showed that artisanal fishing activities were characterised by qualitative and quantitative differences between the Jurumirim and Barra Bonita reservoirs, with a greater gross per capita income found among fishers at the Barra Bonita. In the Jurumirim Reservoir, fishing activities target native species. In contrast, fishers in the Barra Bonita Reservoir focus mainly on exotic species, particularly the Nile tilapia, and employ fishing techniques that are most appropriate for catching such fish. Due to high fishery productivity, the artisanal fishers at the Barra Bonita Reservoir had a greater gross per capita income than fishers from the Jurumirim Reservoir. Thus, we concluded that anthropogenic impacts influenced the artisanal fishing, raising fish production in the Barra Bonita Reservoir. Notwithstanding these results, we recommend that managers use the Jurumirim Reservoir fishery as a management model for artisanal fisheries and as a conservation strategy. Such an approach will promote environmental responsibility as well as the long term sustainability of this fishery.

\section{Acknowledgments}

The first author is grateful for the support of the Departamento de Zoologia and Departamento de Morfologia, Universidade Estadual Paulista, câmpus Botucatu, for supporting this study. The Brazilian government is also acknowledged for granting a scholarship that made this study possible. We also thank the research team, technicians and students from the Fish Ecology Laboratory for their help during all stages of our research programme. Dr. Rodrigo Silva da Costa, of the Universidade Federal Rural do Semi-Árido, is thanked for his help with the statistical analyses and the two anonymous reviewers and the editor, Dr. Fernando Pelicice, are thanked for their helpful suggestions.

\section{Literature Cited}

Agostinho, A. A., S. M. Thomaz \& L. C. Gomes. 2005. Conservation of the biodiversity of Brazil's inland waters. Conservation Biology, 19: 646-652.

Agostinho, A. A., L. C. Gomes \& F. M. Pelicice. 2007. Ecologia e manejo de recursos pesqueiros em reservatórios do Brasil. Maringá, Eduem. 
Agostinho, A. A., F. M. Pelicice \& L. C. Gomes. 2008. Dams and the fish fauna of the Neotropical region: impacts and management related to diversity and fisheries. Brazilian Journal of Biology, 68:1119-1132.

Allan, J. D., R. Abel, Z. Hogan, C. Revenga, B. W. Taylor, R. L. Welcomme \& K. O. Winemiller. 2005. Overfishing of inland waters. BioScience, 55: 1041-1051.

Alvares, E. S. S., M. A. S. Canelas, R. G. Costa, L. G. Dias, H. N. Ribeiro-Mendes \& R. M. Pinto-Coelho. 2000. A pesca na represa da Pampulha, Belo Horizonte-MG. Pp. 375-382. In: Anais do V Simpósio de Ecossistemas Brasileiros: Conservação. Vitória, Universidade Federal do Espírito Santos.

Amarasinghe, U. S. 2002. The fishery and population dynamics of Oreochromis mossambicus and Oreochromis niloticus (Oesteichthyes, Cichlidae) in a shallow irrigation in Sri Lanka. Asian Fishiries Science, 15: 7-20.

Attayde, J. L., N. Okun, J. Brasil, R. Menezes \& P. Mesquita. 2007. Impactos da introdução da tilápia do Nilo, Oreochromis niloticus, sobre a estrutura trófica dos ecossistemas aquáticos do bioma Caatinga. Oecologia Brasiliensis, 3: 450-461.

Attayde, J. L., J. Brasil \& R. A. Menescal. 2011. Impacts of introducing Nile tilapia on the fisheries of a tropical reservoir in North-eastern Brazil. Fisheries Management and Ecology, 18: 437-443.

Averhoff, O. R. L. 1999. Fish yields in a Cuban reservoir and relationships with some morphometric and edaphic parameters. Lake \& Reservoir: Research Managament, 4: 75-83.

Barrella, W. \& M. Petrere Jr. 2003. Fish community alterations due to pollution and damming in Tietê and Paranapanema rivers (Brazil). River Research and Application, 19: 59-76.

Beard, T. D., R. Arlinghaus Jr., S. J. Cooke, P. B. McLntyre, S. De Silva, D. Bartley \& I. G. Cowx. 2011. Ecosystem approach to inland fisheries: research needs and implementation strategies. Biology Letters, 7: 481-483.

Britski, H. 1972. Peixes de água doce do Estado de São Paulo. Pp. 79-108. In: Branco, S. M. (Ed.). Poluição e Piscicultura. São Paulo, Faculdade de Saúde Publica da Universidade Estadual Paulista e Instituto de Pesca - CPRN-AS.

Britski, H., K. Z. S. Silimon, B. S. Lopes. 1999. Peixes do Pantanal. Manual de identifícação. Corumbá, Embrapa-SPI.

Câmara, J. J. C., R. A. Santos, E. C. Campos \& J. M. Barbosa. 1988. Pesca de batida: um método eficiente para a captura de tilápias preta e do Nilo, utilizado na represa de Marimbondo, Rio Grande, limite centro-oeste do Estado de São Paulo, $11^{\text {th }}$ ed., São Paulo, Boletim Técnico do Instituto de Pesca.

Caraballo, G. P. 2009. Efecto de tilapia Oreochromis niloticus sobre la producción pesquera del embalse el Guájaro Atlántico Colombia. Revista MVZ, 14: 1796-1802.

Carvalho, E. D. \& V. F. B. Silva. 1999. Aspectos ecológicos da ictiofauna e da produção pesqueira do reservatório de Jurumirim (Alto do Paranapanema, São Paulo). Pp. 769-800. In: Henry, R. (Ed.). Ecologia de reservatórios: estrutura, função e aspectos sociais. Botucatu, FUNDIBIO-FAPESP.

Carvalho, E. D., R. J. Castro, V. F. B. Silva \& A. P. Vidotto. 2003. A estrutura das assembléias de peixes nas zonas de ecótono da represa de Jurumirim (Alto rio Paranapanema, SP). Pp. 249278. In: Henry, R. (Ed.) Ecótonos nas interfaces dos ecossistemas aquáticos. São Carlos, RiMA.

Castro, F. \& A. Begossi. 1995. Ecology of fishing on the Grande River (Brazil): technology and territorial rights. Fisheries Research, 23: 361-373.
Castro, R. J., F. Foresti \& E. D. Carvalho. 2003. Composição e abundância da ictiofauna na zona litorânea de um tributário, na zona de sua desembocadura no reservatório de Jurumirim, Estado de São Paulo, Brasil. Acta Scientiarum Biological Science, 25: 63-70.

CESP, Companhia Energética de São Paulo. 1998. Conservação e manejo nos reservatórios: limnologia, ictiologia e pesca. Série Divulgação e Informação, 220. São Paulo, Companhia Elétrica de São Paulo, Departamento de Estudos e Planejamento Ambiental, 166p.

David, G. S., E. D. Carvalho, J. L. C. Novaes \& G. F. Biondi. 2006. A tilápia do Tietê: desafios e contradições da pesca artesanal de tilápias nos reservatórios hipertróficos do médio Tietê. Panorama da Aquicultura, 97: 24-27.

De Silva S., R. P. Subasinghe, D. M. Bartley \& A. Lowther. 2004. Tilapias as alien aquatics in Asia and the Pacific: a review. Roma, FAO Fisheries Technical Paper $\mathrm{N}^{\circ} 453$.

Dudgeon, D., A. H. Arthimgton, M. O. Gessner, Z. Kawabata, D. J. Knowler, C. Lévêque, R. J. Naiman, A. Prieur-Richard, D. Soto, M. L. J. Stiassny \& C. A. Sullivan. 2006. Freshwater biodiversity: importance, threats, status and conservation challenges. Biological Reviews, 81: 163-182.

Duponchelle, F., P. Cecchi, D. Corbin, J. Nuñez \& M. Legendre. 2000. Variations in fecundity and egg size of female Nile tilapia, Oreochromis niloticus, from man-made lakes of Côte d'Ivoire. Environmental Biology of Fishes, 57: 155-170.

Eco Consultoria Ambiental e Comercio Ltda, 2001. Limnologia, ictiologia e recursos pesqueiros: período de junho 2000 a julho de 2001. Promissão, Programas de gestão ambiental AES Tietê S/A.

Esteves, F. \& F. Meirelles-Pereira. 2011. Eutrofização artificial. Pp. 625-656. In: Esteves, F. (Ed.) Fundamentos de limnologia. $3^{\mathrm{a}}$ ed., Rio de Janeiro, Editora Interciência.

Fernando, C. H. \& J. Holèík. 1991. Fish in reservoirs. Internacionale Revue der Gesamten Hydrobiologie, 76: 149-167.

Figueredo, C. C. \& A. Giani. 2005. Ecological interactions between Nile tilapia (Oreochromis niloticus, L.) and the phytoplanktonic community of the Furnas Reservoir (Brazil). Freshwater Biology, 50: 1391-1403.

Franco De Camargo, S. A. \& M. Petrere Jr. 2004. Social and financial aspects of the artisanal fisheries in the middle São Francisco River, Minas Gerais, Brazil. Fisheries Management and Ecology, 8: 163-171.

Godoy, M. P., 1975. Peixes do Brasil. Subordem Characoidei Bacia do Rio Mogi Guassu. Piracicaba, Editora Franciscana.

Gubiani, É. A., L. C. Gomes, A. A. Agostinho \& E. K. Okada. 2007. Persistence of fish populations in the upper Paraná river: effects of water regulation bay dams. Ecology of Freshwater Fish, 16: 191-197.

Han, B. P. \& H. J. Dumont. 2011. Reservoirs of Guangdong province, South China: an increasing threat of eutrophication. Oecologia Australis, 15: 643-654.

Henry, R., M. G. Nogueira, M. L. M. Pompeo \& V. MoschiniCarlos. 2006. Annual and short-term variability in primary productivity by phytoplankton and correlated abiotic factors in the Jurumirim reservoir (São Paulo, Brazil). Brazilian Journal of Biology, 66: 239-261.

Hoeinghaus, D. J., A. A. Agostinho, L. C. Gomes, F. M. Pelicice, E. K. Okada, J. D. Latini, E. A. L. Kashiwaqui \& K. O. Winemiller. 2009. Effects of river impoundment on ecosystem services of the largest tropical Rivers: embodied energy and market value of artisanal fisheries. Conservation Biology, 23: 1222-1231. 
Instrução do Ministro do Meio Ambiente $N^{\circ}$ 26, 2009. http:// www.ibama.gov.br/documentos-recursos-pesqueiros/instrucaonormativa. Accessed 22 August 2011.

Jackson, D. C. \& G. Marmulla. 2001. The influence of dams on river fisheries. Pp. 1-44. In: Marmulla, G. (Ed.). Dams, fish and fisheries: opportunities, challenges and conflict resolution. Rome, FAO Fisheries Department.

Kester, C. T., S. A. Osofero \& J. A. Daramola. 2007. Assessment of the fisheries potential of Ero reservoir, Ekiti State, Nigeria. Agricultural Journal, 2: 721-725.

La Porta, G., V. Angeli, A. Bicchi, A. Carosi, G. Pedicillo, P. Viali \& M. Lorenzoni. 2010. Variations in the fish community in lake Piediluco (Italy) caused by changes in the lake's trophic status and the introduction of alien species. Journal of Applied Ichthyology, 26: 53-59.

Lowe-McConnell, R. H. 1987. Ecological studies in tropical fish communities. Cambridge, Cambridge University Press.

McCrary, J. K., B. R. Murphy, J. R. Stauffer \& S. S. Hendrix. 2007. Tilapia (Teleostei: Cichlidae) status in Nicaraguan natural waters. Environmental Biology Fishes, 80: 78-107.

Minte-Vera, C. V. \& M. Petrere Jr. 2000. Artisanal fisheries in urban reservoirs: a case study from Brazil (Billings Reservoir, São Paulo metropolitan region). Fisheries Management and Ecology, 7: 537-549.

Morosawa, T. 2011. Hypoxia tolerance of three native and three alien species of bitterlings inhabiting Lake Kasumigaura, Japan. Environmental Biology of Fishes, 91: 145-153.

Nilsson, C., A. Reidy, M. Dynesius \& C. Revenga. 2005. Fragmentation and flow regulation of the world's large river systems. Science, 308: 405-408.

Nissanka, C., U. S. Amarasingue \& S. De Silva. 2000. Yield predictive models for Sri Lankan reservoir fisheries. Fisheries Management and Ecology, 7: 425-436.

Nogueira, M. G., M. Ferrareze, M. L. Moreira \& R. M. Gouvêia. 2010. Phytoplankton assemblages in a reservoir cascade of a large tropical - subtropical river (SE, Brazil). Brazilian Journal of Biology, 70: 781-793.

Novaes, J. C. L. \& E. D. Carvalho. 2009. Recursos pesqueiros oriundos da pesca artesanal no reservatório de Jurumirim, Rio Paranapanema, Alto Paraná, Brasil. Boletim do Instituto de Pesca de São Paulo, 35: 553-565.

Novaes, J. C. L. \& E. D. Carvalho. 2011. Artisanal fisheries in a Brazilian hypertrophic reservoir: Barra Bonita reservoir, middle Tietê River. Brazilian Journal of Biology, 74: 821-832.

Okada, E. K., J. Gregoris, A. A. Agostinhos \& L. C. Gomes. 1997. Diagnóstico da pesca profissional em dois reservatórios do rio Iguaçu. Pp . 293-318. In: Agostinho, A. A. \& L. C. Gomes, (Eds.). Reservatório de Segredo: bases ecológicas para o manejo. Maringá, Eduem.

Okada, E. K., A. A. Agostinho \& L. C. Gomes. 2005. Spatial and temporal gradients in artisanal fisheries of a large Neotropical reservoir, the Itaipu Reservoir, Brazil. Canadian Journal of Fisheries and Aquatic Science, 62: 714-724.
Paiva, M. P., M. Petrere Jr., A. J. Petenate, F. H. Nepomuceno \& E. A. Vasconcelos. 1994. Relationship between the number of predatory of species and fish yield in large North-eastern Brazilian reservoirs. Pp. 120-129. In: Cowx, I. G. (Ed.) Rehabilitation of freshwater fisheries. London, Fishing News Books.

Pelicice, F. M. \& A. A. Agostinho. 2009. Fauna fish destruction after the introduction of a non-native predator (Cichla kelberi) in a Neotropical reservoir. Biological Invasions, 11: 1789-1801.

Petesse, M. L., M. Petrere Jr. \& R. J. Spigolon. 2007. The hydraulic management of the Barra Bonita reservoir (SP, Brazil) as a factor influencing the temporal succession of its fish community. Brazilian Journal of Biology, 63: 443-445.

Petrere Jr., M. 1996. Fisheries in large tropical reservoirs in South America. Lake Reservoir: Research and Management, 2: 111133.

Quirós, R. \& M. B. Boveri. 1999. Fish effects on reservoir tropical relationships. Pp. 529-546. In: Tundisi, J. G. \& M. Straškraba. (Eds.). Theoretical reservoir ecology and its applications. São Carlos, International Institute of Ecology.

Sato, Y. \& E. V. Sampaio. 2006. A ictiofauna da região do Alto São Frascisco, com ênfase no reservatório de Três Marias, Minas. Pp. 251-274. In: Nogueira, M. G., R. Henry \& A. Jorcin. (Eds.). Ecologia de reservatórios; impactos potenciais, ações de manejo e sistema em cascata. São Carlos, Editora RiMA.

Silvano, R. A. M. \& A. Begossi. 2001. Seasonal dynamics of a fishery on the Piracicaba river (Brazil). Fisheries Research, 51: 69-86.

Smith, V. H. \& D. W. Schindler. 2009. Eutrophication science: where do we go from here? Trends in Ecology and Evolution, 24: 201207.

Starling, F., X. Lazzaro, C. Cavalcanti \& R. Moreira. 2002. Contribution of omnivorous tilapia to eutrophication of a shallow tropical reservoir: evidence from a fish kill. Freshwater Biology, 47: 2443-2452.

Sugunan, V. V. 2000. Ecology and fishery management of reservoirs in India. Hydrobiologia, 430: 121-147.

Tammi, J., A. Lappalainen, J. Mannio, M. Rask \& J. Vourenmaa. 1999. Effects of eutrophication on fish and fisheries in Finnish lakes: a survey based on random sampling. Fisheries Management and Ecology, 6: 173-186.

Tundisi, J. G., T. Matsumura-Tundisi \& D. S. Abe. 2008. Ecological dynamics of the Barra Bonita (Tietê River, SP, Brasil) reservoir: implications for its biodiversity. Brazilian Journal of Biology, 68: 1079-1098.

Walter, T. \& Petrere Jr., M. 2007. The small-scale urban reservoir fisheries of Lago Paranoá, Brasília, DF, Brazil. Brazilian Journal of Biology, 67: 9-21.

Wolos, A., B. Zdanowski \& M. Wierschowska. 2009. Changes in the trophic state of Lake Niegocin based on physical, chemical, biological, and commercial fisheries data. Archives of Polish Fisheries, 17: 179-194.

Submitted April 30, 2012

Accepted January 9, 2013 by Fernando Mayer Pelicice

Published June 28, 2013 